\title{
Brazilian Undergraduate Students' Perceptions of the Role of Social Media in Online Recruitment for Internship Positions
}

\author{
Clarisse Halpern1, Bruno Halpern², Isabel Balloussier Cerchiaro ${ }^{3}$ \\ ${ }^{1}$ Department of Curriculum, Instruction, and Culture, Florida Gulf Coast University, Fort Myers, USA \\ ${ }^{2}$ Department of Leadership, Technology, and Research, Florida Gulf Coast University, Fort Myers, USA \\ ${ }^{3}$ Departamento de Administração, Universidade Federal Fluminense, Macaé, Brazil \\ Email: clari_halpern@hotmail.com, brunohalpern@gmail.com, icerchiaro@uol.com.br
}

How to cite this paper: Halpern, C., Halpern, B., \& Cerchiaro, I. B. (2020). Brazilian Undergraduate Students' Perceptions of the Role of Social Media in Online Recruitment for Internship Positions. Journal of Human Resource and Sustainability Studies, 8, 294-311. https://doi.org/10.4236/jhrss.2020.83017

Received: August 7, 2020

Accepted: August 30, 2020

Published: September 2, 2020

Copyright $\odot 2020$ by author(s) and Scientific Research Publishing Inc. This work is licensed under the Creative Commons Attribution International License (CC BY 4.0).

http://creativecommons.org/licenses/by/4.0/

\begin{abstract}
The study investigated undergraduate students' perceptions of social media's role in online recruitment for internships in Brazil. A qualitative multiple case study was applied using semi-structured interviews and direct observations of eight participants. Two themes emerged from the content analysis: vague internship postings and application barriers. The findings indicate that the information published on social media was insufficient to engage students to apply for the opened positions, and the format of online resumes prevented students from continuing the applications. Recommendations are offered to improve the recruitment processes of undergraduate interns using social media. In conclusion, the internship ads were left untouched by respondents due to the imprecision of their content, despite the ease of access provided by advanced communication technologies.
\end{abstract}

\section{Keywords}

Undergraduate Students, Online Recruitment, Social Media, Internships, Qualitative Case Study

\section{Introduction}

The field of Human Resource Management (HRM) has undergone significant changes in recent decades with the introduction of the internet and information and communication technologies (ICT) in recruitment and selection processes. In this scenario, human resources (HR) professionals increasingly resort to social media to advertise positions and hunt for potential applicants (Araújo \& Ramos, 2002), thus, contributing to the organizational needs, the job market 
demands, and feeding a "war for talent" within and across organizations (Carvalho et al., 2012; Lievens et al., 2002).

Similarly, online recruitment gained preference among potential applicants searching for positions online (Al-Khanak \& Mahmood, 2014; Duarte Neto, 2011; Plessis \& Frederick, 2012). The "target audience" for online recruitment seems to be individuals who have been experiencing, from an early age, the intense transformations of ICT, centralizing their activities, relationships and, consequently, are more susceptible to pursue their education and find internships online (Fekula, 2010; Halpern \& Halpern, 2018; Thomas \& Ray, 2000). These individuals are among undergraduate students seeking internship positions. As a result, HR professionals resorted to marketing strategies in social media to capture the attention of these individuals, while competing with the mesmerizing and yet distracting features of the online world (Halpern \& Halpern, 2018).

Previous studies explored how job applicants display and perceive their images on social media profiles, and how they perceive hiring organizations' Facebook profiles (Brown \& Vaughn, 2011; Frasca \& Edwards, 2017; Stoughton et al., 2015). However, no studies explored undergraduate students' perceptions and experiences searching and applying to internship positions on social media. Thus, in this paper, we aimed to answer the following research questions: How do undergraduate students perceive the role of social media in online recruitment for internship positions? In what ways do undergraduate students engage in social media when searching and applying for internship positions? In what ways are undergraduate students' decision to apply for internship positions affected by the content and style of the positions advertised on social media?

\section{From Traditional to Online Recruitment Processes}

Recruitment processes as part of organizational praxis were affected by changes in the field of HRM, Business Administration, and Management Studies deeply connected to social, cultural, economic, political, and historical contexts (Gil, 2017). In Brazil, where the research was conducted, the early 1930s were marked by recruitment processes being limited to candidates registering their names in "placement registration books" and waiting to be offered a job position (Tose, 1997). Subsequently, the establishment of Brazil's Ministry of Labor and Employment inspired structural changes in HR processes in which administrative procedures were adopted to recruit and select employees (Marras, 2016) and recruitment was carried out by newspapers and radio calls (Araújo \& Garcia, 2014). Continually, HR processes and procedures became more formal and organized (Fleury \& Fischer, 1992), including psychological assessment and interviews to recruit and select employees (Malvezzi, 1979). In the 1980s, profound changes impacted organizations across the country, inspired by the reengineering processes in the United States, and affecting the organizations' productivity and employees' subjectivity. As a result, the world witnessed the rise of out- 
sourcing companies, particularly those in charge of running non-core operations such as personnel recruitment and selection (Lacombe, 2009; Milkovich \& Boudreau, 2000). Then, recruitment was carried out in newspapers, corporate newsletters, intramural posters, radio, and television calls (Snell et al., 2016).

Later and until this day, the internet has broadened the possibilities for online recruitment and selection, allowing organizations and outsourcing companies to eliminate lengthy processes. Thus, online recruitment became a low-cost strategy with significant benefits and high market penetration, which allowed organizations to create a database for applicants' information and use statistical and comparative data analysis for its benefit (Araújo \& Ramos, 2002). Besides, social media became the ideal medium that ensured rapid job and internships postings dissemination, while promoting users' interaction and attracting their attention to potential employers (Duarte Neto, 2011; Galanaki, 2002; Halpern \& Halpern, 2018).

\section{Marketing and Online Recruitment}

An increasingly competitive and demanding job market instigates rivalry among organizations and potential applicants for job positions. In this scenario, locating, attracting, and retaining high-potential individuals have become the main priorities of organizations (Finnigan, 2013; Ostrofsky, 2013). Thus, HR professionals have been using marketing strategies to determine the focus of their recruitment efforts, the message (and mean) to advertise and communicate the organization's attributes to attract their target audience and ensure applications in the advertised positions (Finnigan, 2013). Consequently, the organizations resorted to employer branding (Phillips \& Gully, 2015), a popular marketing strategy that creates a favorable organizational image to its potential applicants.

Besides, organizations' leaders have been investing in marketing communication strategies online (Kotler \& Keller, 2012), particularly on social media (Snell et al., 2016) to attract undergraduate students to internship positions (Halpern Sicuro, 2016). Notably, the terminologies and definitions used in this section originated in marketing communication strategies theories and were adapted to fit the description and its intersection with current HR processes. These strategies inform potential applicants about the organization, emphasizing its positive characteristics. Consequently, the organization earns their target audience admiration and preference when applying to the available positions, and reinforcing its positive attributes by publishing videos and pictures of employees happy to have made 'the right decision' when becoming part of it (Kotler \& Keller, 2012).

The public scope of such marketing strategies confers legitimacy and high market penetration of the postings themselves, while also reaching several potential applicants. Once the target audience is familiar with the organization, its characteristics, and positive attributes, they are more likely to apply for its positions (Gatewood et al., 1993; Turban et al., 2001). Continual exposure of internship postings seems to be directly associated with the target audience's increased 
positive perception about them, followed by the application and participation in the selection processes. Hence, attractive and effective websites, microsites, and social media profiles draw the attention of individuals that are more likely to apply for the advertised positions. Effective social media platforms build bridges that bring the hiring organization and its target audience closer, favoring the application process (Nakayama et al., 2006). Consequently, social media has become an integral part of online recruitment processes in organizations worldwide (Han \& Han, 2009).

It is noteworthy that sharing and publishing internship postings are not restricted to HR professionals and outsourcing companies, as the nature and dynamics of online environments allow individuals to share content contributing to the "epidemic" effect of jobs and internships postings on a large scale (Rocha et al., 2013). Ultimately, the increased complexity involved in recruitment processes in the last decade has required that HR professionals adapt to market demands and learn new skills, amalgamating HR and marketing functions and expertise into their professional repertoire to find the best-fitting applicants to fill their positions and organizational needs.

\section{Limitations of Online Recruitment}

Despite the benefits of online recruitment, it offers disadvantages such as the websites' poor navigability which impacts applications (Handler \& Hunt, 2003), especially the process of filling out information on online resumes. The fill-in fields tend to be very specific, standardizing information and forcing individuals to choose among limited options to describe their professional profile and career interests. This induces the individual to include information that might ignore subjective factors (Halpern Sicuro, 2016). While online recruitment brings organizations closer to potential applicants, it can also alienate them because the virtual environment is impersonal and does not allow recruiters to access other dimensions of the applicants' subjectivity (Rudich, 2000). Thus, online recruitment creates an illusion of proximity that results in the exclusion of individuals that could potentially be hired by the organization (Handler \& Hunt, 2003).

The lack of adequate training for HR professionals and managers to work with online recruitment and resume databases can compromise the processes (Sullivan, 2003). Daily, the task of training personnel became secondary as large HR companies typically deal with the screening of thousands of resume applications per week. Therefore, recruitment becomes more mechanical, pragmatic, and superficial, focusing too much on objective skills and characteristics than finding the subjectivity of individual applicants (Halpern Sicuro, 2016).

As a result, the recruitment process may compromise the quality of the HR professional assessment of the applicants' resumes, given that they are pressed for time and results (Halpern Sicuro, 2016). In this vein, the overflow of resumes and applications are negative aspects of online recruitment, contributing to the HR professional loss of agility and productivity (Borck, 2002; Dessler, 2014). Consequently, fewer resumes are taken into consideration. Sullivan (2011) post- 
ulated that the actual chances of a resume being analyzed are slim, particularly when the position is in a large organization. Finally, HR professionals generally do not have time to give applicants feedback, resulting in anxiety and frustration in the process (Handler \& Hunt, 2003), especially among undergraduate students.

\section{Materials and Methods}

A qualitative multiple case study method (Stake, 2005; Yin, 2005) investigated undergraduate students' engagement on social media, seeking to understand their decision process when searching and applying for internship positions, therefore, constituting a contemporary case setting (Creswell \& Poth, 2018; Yin, 2005). The cases described how undergraduate students were captured and involved by recruitment strategies on social media to become candidates of selection processes. Besides, using multiple, comparative case studies, the researchers were able to contrast each participants' unique perspectives and experiences.

\subsection{Case Setting}

It is paramount to explain the context of internships in Brazil, as they may differ from those of other countries. Internships are essentially an educational endeavor (Brasil, 2008) that train undergraduate students in their chosen professions to ultimately become part of the organizations' workforce (Rocha-de-Oliveira \& Piccinini, 2012; Scalabrin \& Molinari, 2013). Nonetheless, in the last two decades, internships have become less of an educational activity and more of a gateway into the job market, particularly in the face of severe unemployment and changes in the organizational labor (IBGE, 2019). Consequently, undergraduate students enroll in internship positions massively, competing to ensure their hiring and professional success upon graduation. Some internship programs offer 70 internship positions, disputed by over 25 thousand applicants (Centro de Integração Empresa-Escola, 2012; Garbin \& Silva, 2016). Thus, students who fail to be admitted into internships face a significant disadvantage in the job market in comparison to those who can.

On the other hand, some organizations take advantage of this situation, transforming their interns into "cheap labor," assigning and demanding more responsibilities from the students as if they were graduated professionals (Rocha-de-Oliveira \& Piccinini, 2012). Students are required to demonstrate advanced skills and competencies to be hired as interns with the promise of securing a job position at the end of the internship contract. By the end of the internship experience, the interns are expected to have become professionals ready to take on more responsibilities (Rocha-de-Oliveira, 2009), despite no guarantees of securing a job position, particularly in times of economic recession.

Consequently, as some of the recruitment and selection processes attract thousands of student-applicants competing for a handful of positions, they become lengthy processes with several steps, from online resume screening, online and face-to-face tests, group dynamics, as well as group and individual inter- 
views with HR professionals and potential supervisors/managers (Banov, 2012). In this context, organizations resort to outsourcing companies to conduct these processes, design microsites devoted to applications and online testing, create Facebook and other social media profiles to advertise the internship positions, and conduct the other steps of the process, like interviews and group dynamics (Halpern Sicuro, 2016; Halpern \& Halpern, 2018; Snell et al., 2016).

\subsection{Data Collection and Analysis}

Conducive to the data collection procedures for case studies, multiple sources of data were used to describe the cases in-depth (Creswell \& Poth, 2018), including individual semi-structured interviews, direct non-participant observations, audiovisual material, and field notes (Yin, 2005). Before the data collection, the research was approved by the university's ethical committee. The participants signed an informed consent form that warranted their right of non-response, withdraw from the study at any time without penalty, and secure the confidentiality of their identities and information using pseudonyms.

The individual semi-structured interviews were conducted via Skype, at the participants' homes, in the environment where the phenomenon under study naturally takes place (Creswell, 2003), that is, where the participants typically access social media to search and apply for internship positions online. The interviews lasted 30 to 90 minutes and aimed to capture the participants' attitudes, beliefs, and experiences while browsing social media websites and apps in search of internship positions (Creswell \& Poth, 2018; Gil, 2019). The direct non-participant observations and audiovisual materials were used to support the information collected during the interviews, capturing the participants' expressions, body language, intonation, and behaviors, providing a more comprehensive understanding of the cases (Creswell, 2003; Denzin \& Lincoln, 2006; Yin, 2005). The field notes taken during the interviews contributed to the case descriptions and observations, including direct quotations as well as the researchers' initial analysis, reactions, insights, and reflections (Patton, 2002).

The audio-recorded interviews were transcribed verbatim. Then, the authors organized the data using open coding (Strauss \& Corbin, 1998) and inductive analysis to discover patterns that resulted in the emergence of themes. Besides, the analysis resulted in the identification of common themes, revealing the context of the cases (Merriam, 1998). Also, the researchers' followed the logic of replication to achieve the theoretical generalization from the cases studied and of new cases (Stake, 2005; Yin, 2005), allowing for a "complete contextual analysis of a few facts or conditions and their interrelationships" (Cooper \& Schindler, 2016: p. 120), aiming to produce new hypotheses and theoretical constructs.

\subsection{Participants}

In alignment with the purpose of investigating the decision process of undergraduate students when searching and applying for internship positions on social media, the participants were recruited on social media. The invitation mes- 
sage to participate in the research was posted in several social media profiles and pages, mainly those in charge of sharing internship positions to undergraduate students. The message emphasized that there would be no compensation in participating in the research and that participation was entirely voluntary. The selection criteria were the following: 1) the participants had to be undergraduate students, and 2) the participants had to be in search of internship positions.

There were no pre-established criteria concerning the participants' majors, stage in their programs of study, or previous internship experiences. Hence, a purposive sample of eight volunteers participated in the study. The participants were majoring in Communication, Journalism, Civil Engineering, Psychology, and Marketing. The participants' ages ranged from 21 to 24 years old $(M=22.5)$. Five participants were female, and three were male. At the time of the interviews, three participants were searching for their first internship; the other five participants were interns but open to new opportunities. The participants were between the fifth and tenth semesters (three to five years) into their programs of study ${ }^{1}$. Table 1 depicts the participants' demographic information.

\subsection{Procedures}

After signing the informed consent form, the participants were instructed to search for internships while browsing social media, explaining out loud their reasons for choosing or refusing to access each, analyzing their choices concerning the style, content, and other aspects of the advertised positions. The participants were told to act as spontaneously as they could, as if no one was watching and recording them, which meant they could browse websites unrelated to internship positions, checking their phones, responding messages, simulating how they would act when they are alone searching for internships online. They were instructed to comment on their decisions and actions, describing what they were doing. The participants' interactions on social media and how they diverted from the search and application for internship positions have been reported previously by another publication (see Halpern \& Halpern, 2018).

Table 1. Participants' demographic information.

\begin{tabular}{ccccc}
\hline Participant $^{a}$ & Age & Gender & Major & Stage in Program of Studies \\
\hline Julia & 22 & Female & Journalism & $8^{\text {th }}$ semester $/ 4^{\text {th }}$ year \\
Victoria & 21 & Female & Journalism & $5^{\text {th }}$ semester $/ 3^{\text {rd }}$ year \\
Gabriela & 23 & Female & Journalism & $9^{\text {th }}$ semester $/ 4^{\text {th }}$ year \\
Laura & 21 & Female & Psychology & $8^{\text {th }}$ semester $/ 4^{\text {th }}$ year \\
Bernardo & 24 & Male & Communication & $8^{\text {th }}$ semester $/ 4^{\text {th }}$ year \\
Clara & 23 & Female & Journalism & $8^{\text {th }}$ semester $/ 4^{\text {th }}$ year \\
Carlos & 23 & Male & Marketing & $8^{\text {th }}$ semester $/ 4^{\text {th }}$ year \\
Ronaldo & 23 & Male & Civil Engineering & $10^{\text {th }}$ semester $/ 5^{\text {th }}$ year
\end{tabular}

a. The names listed are pseudonyms.

${ }^{1}$ In Brazil, undergraduate programs are referred by semesters rather than years. The duration of undergraduate programs is of four to six years (or eight to 12 semesters), depending on the major. 


\section{Findings}

From the content data analysis, two themes emerged from the participants' narratives: 1) vague internship postings, and 2) application barriers. Both indicated that, it is particularly important for undergraduate students to have complete information concerning internship positions' postings on social media, as well as easy to fill-out online resume forms to ensure their application and continuation in the recruitment and selection process.

\subsection{Vague Internship Postings}

The participants concluded that the internship positions' postings needed more explicit information to prompt them to apply for the open positions. The lack of clear communication concerning the hiring organization's location, salary, benefits, as well as a clear description of the internships' required activities hindered their interest to apply or to work for the organization. For example, Julia said, "See? This ad doesn't have enough details. It says nothing! Lots of pictures and unnecessary information and, for what? It doesn't even have the company's name. I refuse to apply!”

Furthermore, the participants described feeling suspicious about internship postings whose contact information contained non-corporate email domains such as Gmail, Hotmail, and others. According to the participants, this aspect was one of the most significant hindrances for applying because such domains tend to be used for personal email accounts, thus, considered unreliable. Victoria commented, “When the email is something like 'recruitment@gmail.com,' it's very vague. It doesn't even show the name of the company. So, I ignore it and don't apply." Gabriela added to this suspicion, "I feel like many organizations pretend to have open positions to get our email for other reasons. It's like recruitment is just a catch for marketing or whatever else they do with our information." Thus, the fear of having their data used for other purposes other than recruitment generated distrust to apply for the positions. Gabriela further expressed her concerns: "When we send our resumes to these websites and emails, it's like a contract, a commitment between the company and ourselves. So, if they use my information for something else, this company is not reliable."

Adding to the list of concerns and distrust is the fact that the descriptions of internship postings do not correspond to the tasks required in actual internships. As Laura commented, "some postings are lies, and you only know once you are admitted into the organization. Then, you realize that your tasks don't match the description in the posting; it's something else." Hence, like other participants, Laura mentioned that posts on Facebook pages responsible for sharing internship openings are more reliable. In the participants' perspectives, Facebook allows other users to share opinions, write reviews, and exchange information about the advertised positions, revealing their real purpose and details.

The participants also commented about vague information concerning the internship postings, including the organizations' address, internship tasks, salary, 
working hours, and others. Bernardo commented, "this [internship] is in Rio de Janeiro. Ok, but Rio is a huge city. I need to know how far I'd have to commute every day. Is it some sort of a secret to specify this kind of information?" Similarly, Carlos said, "I don't like to apply for a position that doesn't have an internship description. This information is super relevant; otherwise, you don't know what to expect." Clara also complained about internship postings that do not specify the tasks that she would perform if admitted. She said,

I prefer when they [postings] tell you exactly what you will do for your internship. This one here just says the internship is in Journalism. Cool, but what will I do?! Take pictures? Write articles? Interview people? Is it too much to ask for more transparency and information?!

Additionally, the participants commented that internship postings with broad requirements are also vague and do not trigger their interest. Bernardo questioned an internship posting from a pharmaceutical industry accepting undergraduate students from all majors, saying, "It says they're [the positions] open for all majors. It's just weird, you know? Is it really open to all majors? After all, what do they want? They gotta be more specific!" When internship postings are too broad, unspecific, and vague, they end up repelling potential applicants. Instead of instigating the students' interest, they do not feel safe applying for those positions. Conversely, recruitment postings should have contents that trigger potential applicants' interests, professional aspirations, and dreams, and that will ultimately make them apply for the internship positions.

According to the participants' experiences, one significant aspect that attracted them to internship postings was the hiring organization's name and reputation. While some participants expressed that they did not feel safe applying for a position offered by an "anonymous" company, conversely, a well-known corporation would evoke a positive impression and raise their hopes of finding better professional opportunities in the future. Bernardo was initially excited for finding an internship position at Google. Nonetheless, he changed his mind after reading the posting more carefully:

I don't know what it [Google] wants. It says, "interns at Google do cool things that matter, working on major projects that impact hundreds of millions of users and making major contributions to our business." That's pretty vague! What do they want me to do? I think they do [these postings] on purpose, it's like a test. Maybe the person they're looking for will sign up, take the risk, without caring about details.

The vagueness of information made Bernardo change his mind about applying for the internship position. He interpreted the lack of details as a strategy to test the applicants' interest. Similarly, Ronaldo said, "if the [posting] is from a well-known company, then I'll definitely be interested. Unless I'm not entirely sure what they want me to do there." Ultimately, limited information about internship postings triggered several questioning and reflections about the purpose of recruitment, despite the organizations' investment in the style and content of the postings. 


\subsection{Application Barriers}

This theme emerged from the participants' perceptions that online resumes were obstacles rather than helpful tools in their application to internship positions' postings online. The absence of fluid navigability in application forms' websites resulted in immediate rejection of the open positions. Besides, the participants were also confused about filling out the information when applying to the opened positions online. Clara commented,

These [online resume] websites are so annoying! They ask many questions that I always leave it blank because I don't even know what they mean. They ask so many useless questions that I doubt someone's going to read them. Can't they just let us upload the resume that we created?!

Clara's complaint illustrated the importance of website usability and navigability (Lee \& Kozar, 2012; Nielsen, 1994), which are related to users' perception of "efficiency when they can achieve goals with a quick visit without putting forth much cognitive effort" (Lee \& Kozar, 2012: p. 451). This aspect can significantly impact organizational attraction (Cober et al., 2003). To that end, it is pivotal that websites are designed so that their navigability is fluid (Palmer, 2002), with language, terminologies, and familiar concepts (Nielsen, 2000). Conversely, the participants commented that online resumes use specific HR terminology that seemed to be directed to HR professionals, not to the applicants, resulting in obstacles to the application processes. It was as if these websites and online resume forms were not created considering their target audience, that is, undergraduate students in search of internship positions. Gabriela explained,

I never know how to fill out these forms. It says here [website], "describe your professional profile." It's so vague like I could write anything! I ended up copying and pasting what I wrote in my own resume because I didn't know what to do. They [HR professionals] don't care that we're just students trying to learn how to navigate in this whole online resume thing. They create websites with names and terms designed for them, not for us.

The participants also questioned online resumes that require applicants to include their social media profiles to be analyzed as part of the selection process. In their opinion, demanding access to their personal social media profiles is an invasion of privacy, as pointed out by two participants:

My Facebook and Instagram profiles are personal, for my friends and family, and it's nobody's business. I think it's wrong when HR professionals ask what I like to post or share. As if those could inform anyone about my professional interests and skills. (Clara).

It doesn't make any sense when companies require access to our social media. It seems like there are no boundaries between our personal and professional lives to these people. My likes and dislikes, what I share and comment are nobody's business and don't affect my ability to work anywhere. (Gabriela).

The participants complained about online resumes forms as significant impediments for their applications. Carlos commented, "it's frustrating, you know? 
The information they [online resumes] ask for is repetitive. Literally, you have to include the same information several times. Couldn't we just upload our resumes and be done with it?!" In a similar vein, the participants criticized that online resumes seem to standardize their information and subjectivities rather than let them express themselves as potential applicants. In this respect, Bernardo said,

I don't like that these websites limit your possibilities to fill out the information about us. You need to include what they want. There are things that we do in life that don't fit their boxes for but are relevant to who we are. So, if you've experienced something that doesn't fit their bill, you need to find a way to include that to be seen by them [HR professionals].

Overall, it seemed that there was a gap between online resumes' websites and the applicants, which resulted in the participants' rejection of the internship positions altogether. The style, usability, and navigability of the websites visited hindered the participants' interest to apply for the internship openings. Therefore, the pivotal moment to get the potential applicants to fill out their information and become part of the selection process was interrupted due to the inefficiency of the online resume websites, regardless of the investments to create a positive image of the organization through employer branding, and build attractive recruitment websites and postings.

\section{Discussion}

The literature on HR practices tends to discuss issues related to the organization's success in a work environment where the application of techniques follows a linear script, in line with pre-established steps. In this model, the human factor, its complexity, and unpredictability are relegated to a secondary level. Recruitment and selection processes are not exempt from neutrality; they are socially and historically constructed, affected by the transformations operating in the field of HR management and business administration over time (Halpern Sicuro, 2016). Previous research on recruitment on social media did not explore undergraduate students' perceptions of its role in recruitment for internships. Most of the literature found on online recruitment was limited to master's theses published in Portugal (Gomes, 2011; Duarte Neto, 2011), publications on the application of marketing as a recruitment tool in the United States (Finnigan, 2013; Hander \& Hunt, 2003; Ostrofsky, 2013; Phillips \& Gully, 2015; Sullivan, 2003), and publications that mention the use of internet in recruitment processes, mainly in Brazilian HR books (Carvalho et al., 2011; Gil, 2017; Nakayama et al., 2006). Although most of the references correlate recruitment and marketing processes, the discussions are superficial, limited to brief comments.

The findings corroborate with Handler and Hunt (2003) statement that many organizations use applicants' information, collected in recruitment websites and emails, for other purposes, trying to convert applicants into consumers of the organization's products and services. Indeed, the participants felt that many or- 
ganizations recruit applicants for positions that are not available. For example, Laura believed that organizations displayed internship positions postings that do not correspond to the internship tasks and responsibilities, which puts at risk the credibility of the organization's image and recruitment and selection processes (Sullivan, 2011). Therefore, it is paramount that organizations gain the confidence of potential applicants by ensuring the transparency of their recruitment and selection processes (Ostrofsky, 2013).

The organization's name and reputation were crucial factors to the participants when searching for internship positions on social media, for example, when Bernardo was excited to find an internship position at Google. The reason is that having an internship in reputable organizations will increase their chances of being hired upon graduation and grow professionally and in their careers (Alsop, 2008; Cavazotte et al., 2012; Erickson, 2008; Huntley, 2006; Ostrofsky, 2013). This finding calls upon recruiters to use employer branding efforts to use the hiring organizations' name and reputation to attract applicants instead of concealing necessary information from applicants on their ads.

It is worth mentioning that seven participants used their computers to participate in the interview, while another one preferred to do all searches by cell phone. The participants demonstrated vast familiarity with social media, which confirms the extent to which social media have become a space for exchange between individuals who communicate and interact, enabling the sharing of content with subjects with similar interests (Bastos \& Santos, 2007; Gomes, 2011). Castells (2003) pointed out that the internet has allowed for the extension of communication between subjects, establishing transformations in the various spheres of social relations, constituting itself as a characteristic feature of contemporaneity that models and establishes trends in behavior and social organization. These are means that enabled free and horizontal communication between individuals, eliminating the presence of traditional intermediaries. Users themselves can search the web in different ways to find internship positions in the job market. Individuals have progressively become more connected to the online environment, having direct and easy access to the posts of internships offered by recruiters, by merely accessing their emails and following up on social media notifications (Halpern Sicuro, 2016).

Several social media compete for the attention of their target audience, that is, the internship applicants, mainly because there is a wide range of online attractions that continually raise students' interest, requiring that tactics of dissemination be highly attractive (Cappelli, 2001; Finnigan, 2013). Marketing communication strategies and the new dissemination technologies highlight the recruitment process, looking for ways to involve a potential applicant. Although social media induces users to make decisions on impulse, attracted by propagandistic formulas, the lack of information decreased the participants' interest. The posts' vagueness reduced the effectiveness of sophisticated marketing communication strategies engendered to capture potential applicants. Besides, it seemed as if the 
participants were looking for the dream internship, incompatible with the reality of the internship and job market (Halpern Sicuro, 2016; Halpern \& Halpern, 2018). They mentioned at least one reason for not applying to several postings found during their search, despite having claimed to be interested in becoming an intern.

It is valid to ascertain that the call for applicants to apply for internships seem to shift in a moment of repulsion, aborting the choice to subscribe to the position. Their harsh opinions should keep recruiters on high alert, stimulating them to review the form, style, content, language, and even their objectives, revising how to convey better the fundamental information about the internship position in the advertised posting. Recruiters must be aware that internship applicants are inexperienced, making adamant need to simplify the process. The resume elaboration might instill doubt and insecurity in any stage of professional life. And if the resume is online, and must be filled out in a specific platform, the information boxes must be elaborated clearly and objectively. Or simply add the option for applicants to attach their already completed resume. After all, incorporating the applicants' needs into the process should be of the highest priority. Presently, there are many means to guide the individual toward resume readiness: magazine stories, newspapers, television, and even university career centers, where 'experts' offer tips in preparing the perfect resume. Vocational counselors and, more recently, coaching services are some of the helping tools, providing training so that applicants learn how to use the proper language that defines their skillset, personal and professional interests, aiming to increase their chances of becoming more invaluable in a competitive market. Nevertheless, none of these matter to a hiring company, or outsourcing recruiting company responsible for selection processes, nor to the website, whose main objective (and not always stated) is to create and feed a resume database to divulge job positions. In this case, what matters most is accelerating the process to keep the market competitive and in constant flow.

Lastly, the goal of hiring companies and recruiters seemed not to be the applicants, but the positions themselves. Therefore, it was not in their interest to "waste time" explaining to their website's users how to fill out online resumes. The participants' frustration was valid considering their intuitive perception that they are not as desired as they were led to believe. Perhaps the gap between both parts represents the existence of implicit objectives, not directly exposed by the hiring companies, linked to other market interests that are kept at bay from potential applicants. Indeed, eye-catching distractions on social media are continually grabbing undergraduate students' attention, requiring recruiters to review the style and content of their online publications to capture potential applicants' attention before they get distracted by something else. During this dispute, unclear information may discourage undergraduate students from applying to a selection process. In a matter of seconds, other topics and attractions may win their interest, more engaging, fun, or even flashy. As a result, the participants 
browsed through other websites with more engaging content, complained about the existing posts, and ended the study without applying to any position available. Immersed in this multisensory scenario, undergraduate students may not apply, despite ease of access. Navigation became the actual protagonist, while the applicants' recruitment depends on an improbable click. The dispute is not restricted among hiring companies in search of high-quality applicants; conversely, the "opponent" seems to be the online environment, highly magnetizing, and mesmerizing (Halpern Sicuro, 2016). Consequently, hiring companies may lose potential, talented applicants due to their shortsightedness, focusing too much on meaningless and unimportant application details that rely on inaccurate, hazy criteria, and expecting undergraduate students to possess skills beyond their experience. Consequently, it feeds insecurity into applicants' minds. Instead of presenting their own set of skills and accomplishments, they feel obligated to try to fit into an application box. Conversely, some hiring companies seem to be more interested in elaborating marketing and employer branding strategies to collect data from applicants rather than focus on the purpose of hiring interns. As a result, the participants perceived the mixed messages and felt discouraged from applying to the positions available.

Another aspect highlighted by the participants was the absence of feedback about the selection processes, leaving them in the dark about how they performed, not even explaining the reasons for their rejection. Factually, when applying, applicants must give up personal information and curriculum, exposing themselves, sometimes without knowing which company or position they applied to. Usually, it becomes a leap of faith. If they are excluded in any of the selection processes' phases, recruiting companies seem not to offer explanations or satisfactions. After all, if ICTs help recruit candidates, simplifying communication between companies and applicants, it is fair to question the reasons why recruiters would fail to use the same technologies to give applicants feedback to learn from the experience and be ready to apply to other opportunities.

\section{Conclusion}

Following Stake's (2005) assertions, our conclusion comprises the lessons learned from the cases. It was clear that the postings on social media did not contain sufficient and transparent information about the hiring companies or the tasks to be performed during the internship, which resulted in the participants' rejection of the opportunities available, regardless of the advanced technologies and marketing strategies employed to attract them. This is particularly important considering that the target audience was comprised of undergraduate students in search of internships who are significantly familiarized with social media and internet browsing.

We recommend that hiring companies and recruiters shall announce internships opportunities that are not vague and make the process of enrolling in each position and its online forms and resumes more accessible to students, under- 
standing that they are novices in the job market and may not be familiar with terminologies and requirements pertinent to the HR field. This study's implications include suggestions to improve HR recruitment and selection of undergraduate students, providing information concerning their perceptions and experiences while navigating on social media in search of internship positions. Furthermore, our study informs educators in the field of HR and business administration to better prepare future professionals to undertake recruitment and selection tasks in the online environment and the digital era. Finally, given the absence of previous studies on undergraduate students' perceptions of social media's role when searching for internship positions, this study intended to serve as an explanatory model, promoting inductions of this particular set of results for a broader scope. The current findings may serve as suggestions for future research carried out with other subjects, perhaps with senior professionals, and in other contexts.

\section{Conflicts of Interest}

The authors declare no conflicts of interest regarding the publication of this paper.

\section{References}

Al-Khanak, S. A. K., \& Mahmood, N. H. N. (2014) Factors Influence Organization Management Towards Using Electronic Recruitment Strategy. Sains Humanika, 2, 47-52.

Alsop, R. (2008). The Trophy Kids Grow Up: How the Millennial Generation Is Shaking Up the Workplace. San Francisco, CA: Jossey-Bass.

Araújo, L. C. G., \& Garcia, A. A. (2014). Human Resource Management: Strategies and Organizational Integration (2nd ed.). Sao Paulo: Atlas.

Araújo, S. F., \& Ramos, A. S. M. (2002). Online Recruitment: Study of the Perceptions of Internet Use in Human Resources Consulting Firms. In XXII Encontro Nacional de Engenharia de Produção. Rio de Janeiro: ABEPRO.

Banov, M. R. (2012). Recruitment, Selection, and Competencies (3rd ed.). Sao Paulo: Atlas.

Bastos, A. V. B., \& Santos, M. V. (2007). Informal Social Networks and Sharing of Meanings about Organizational Change. Revista de Administração de Empresas, 47, 27-39. https://doi.org/10.1590/S0034-75902007000300003

Borck, J. R. (2002). Recruiting Systems Control Resume Chaos. InfoWorld, 22, 47-48.

Brasil (2008). Lei de Estágio (11.788) [Internship Law]. http://www.planalto.gov.br/ccivil 03/ ato2007-2010/2008/lei/l11788.htm

Brown, V. R., \& Vaughn, E. D. (2011). The Writing on the (Facebook) Wall: The Use of Social Networking Sites in Hiring Decisions. Journal of Business and Psychology, 26, 219-225. https://doi.org/10.1007/s10869-011-9221-x

Cappelli, P. (2001). Making the Most of Online Recruiting. Harvard Business Review, 79, 139-146.

Carvalho, A. V., Nascimento, L. P., \& Serafim, O. C. G. (2012). Human Resource Management (vol. 2, 2nd ed.). Boston, MA: Cengage Learning. 
Castells, M. (2003). The Internet Galaxy: Reflections on the Internet, Business, and Society. Oxford: Oxford University Press. https://doi.org/10.1093/acprof:oso/9780199255771.001.0001

Cavazotte, F. S. C. N., Lemos, A. H. C., \& Viana, M. D. A. (2012). New Generations in the Job Market: Renewed Expectations or Traditional Ideals? Cad. EBAPE.BR, 10, 166-180. https://doi.org/10.1590/S1679-39512012000100011

Centro de Integração Empresa-Escola (2012). Myths and Truths in the Hunt for New Talent. Revista Agitação, 106, 22-29. http://www.ciee.org.br/portal/biblioteca-digital/content/revista/pdf/106.pdf

Cober, R. T., Brown, D. J., Levy, P. E., \& Cober, A. B. (2003). Organizational Web Sites: Web Site Content and Style as Determinants of Organizational Attraction. International Journal of Selection and Assessment, 11, 158-169. https://doi.org/10.1111/1468-2389.00239

Cooper, D. R., \& Schindler, P. S. (2016). Research Methods in Business Administration (12th ed.). New York: McGraw Hill.

Creswell, J. W. (2003). Research Design: Qualitative, Quantitative, and Mixed Methods Approaches (2nd ed.). Thousand Oaks, CA: SAGE Publishing.

Creswell, J. W., \& Poth, C. N. (2018). Qualitative Inquiry and Research Design: Choosing Among Five Approaches (4th ed.). Thousand Oaks, CA: SAGE Publishing.

Denzin, N. K., \& Lincoln, Y. S. (2006). Qualitative Research Planning: Theories and Approaches (2nd ed.). Porto Alegre: Artmed.

Dessler, G. (2014). Human Resource Management (2nd ed.). London: Pearson.

Duarte Neto, J. E. (2011). Social Media and Human Resources Recruitment: The Recruiter Profile. Master's Thesis, Porto: Universidade do Porto.

https://repositorio-aberto.up.pt/bitstream/10216/62138/1/000150204.pdf

Erickson, T. (2008). Plugged In: The Generation Y Guide to Thriving at Work. Boston, MA: Harvard Business Press.

Fekula, M. J. (2010). Perpetual Enrollment Online Courses: Advantages, Administration, and Caveats. Online Journal of Distance Learning Administration, 13, 1-10.

Finnigan, D. (2013). Recruiting Is Marketing: 4 Lessons Your HR Team Can Learn from the Marketing Department. Electronic Recruiting Exchange.

Fleury, M. T. L., \& Fischer, R. M. (1992). Labor Relations and Management Policieis: The History of Current Issues. Revista de Administração RAUSP, 27, 5-15.

Frasca, K. J., \& Edwards, M. R. (2017). Web-Based Corporate, Social and Video Recruitment Media: Effects of Media Richness and Source Credibility on Organizational Attraction. International Journal of Selection and Assessment, 25, 125-137.

https://doi.org/10.1111/ijsa.12165

Galanaki, E. (2002). The Decision to Recruit Online: A Descriptive Study. Career Development International, 7, 243-251. https://doi.org/10.1108/13620430210431325

Garbin, A. de C., \& Silva, H. A. (2016). Quero Trabalhar! A Experiência Marcante dos Processos Seletivos na Subjetividade de Jovens Universitários [I Want to Work: The Outstanding Experience of Selective Processes in the Subjectivity of University Students]. Cadernos de Psicologia Social do Trabalho, 19, 77-88. https://doi.org/10.11606/issn.1981-0490.v19i1p77-88

Gatewood, R. D., Gowan, M. A., \& Lautenschlager, G. J. (1993). Corporate Image, Recruitment Image, and Initial Job Choice Decisions. Academy of Management Journal, 36, 414-427. https://doi.org/10.2307/256530 
Gil, A. C. (2017). Human Resource Management: Focus on Strategic Positions (2nd ed.). Sao Paulo: Atlas.

Gil, A. C. (2019). Methods and Techniques of Social Science Research (7th ed.). Sao Paulo: Atlas.

Gomes, A. F. P. (2011). Recruitment in Social Media. Master's Thesis, Universidade Técnica de Lisboa.

https://www.repository.utl.pt/bitstream/10400.5/3394/1/Recrutamento\%20redes\%20so ciais\%20on-line.pdf

Halpern Sicuro, C. (2016). Waiting for a Click: The Role of Social Media in the Online Recruitment for Undergraduate Internships. Master's Thesis, Universidade Federal Fluminense. https://app.uff.br/riuff/handle/1/3970

Halpern, C., \& Halpern, B. (2018). Diversions: Obstacles for Undergraduate Students When Applying for Internship Positions Online. Open Journal of Business and Management, 6, 165-182. https://doi.org/10.4236/ojbm.2018.61011

Han, J., \& Han, J. (2009) Network-Based Recruiting and Applicant Attraction in China: Insights from Both Organizational and Individual Perspectives. The International Journal of Human Resource Management, 20, 2228-2249.

https://doi.org/10.1080/09585190903239633

Handler, C., \& Hunt, S. (2003). Beyond the Status Quo: 3 Innovative Sourcing Tools (pp. 1-5). Electronic Recruiting Exchange.

Huntley, R. (2006). The World According to Y: Inside the New Adult Generation. Sydney: Allen \& Unwin.

IBGE, Instituto Brasileiro de Geografia e Estatística (2019). Desemprego [Brazilian Census Unemployment]. https://www.ibge.gov.br/explica/desemprego.php

Kotler, P., \& Keller, K. L. (2012). Marketing Management (14th ed.). London: Pearson.

Lacombe, F. J. M. (2009). Human Resources: Principles and Tendencies (2nd ed.). Saraiva.

Lee, Y., \& Kozar, K. A. (2012). Understanding of Website Usability: Specifying and Measuring Constructs and Their Relationships. Decision Support Systems, 52, 450-463. https://doi.org/10.1016/j.dss.2011.10.004

Lievens, F., van Dam, K., \& Anderson, N. (2002). Recent Trends and Challenges in Personnel Selection. Personnel Review, 31, 580-601. https://doi.org/10.1108/00483480210438771

Malvezzi, S. (1979). The Role of Psychologists in Human Resouces: A Study of the City of São Paulo. Master's Thesis, São Paulo: Pontifícia Universidade Católica de São Paulo.

Marras, J. P. (2016). Human Resource Management: From Operations to Strategies (15th ed.). Saraiva.

Merriam, S. B. (1998). Qualitative Research and Case Study Applications in Education. San Francisco, CA: Jossey-Bass.

Milkovich, G. T., \& Boudreau, J. W. (2000). Human Resource Management. Sao Paulo: Atlas.

Nakayama, M. K., Garziera, A., \& Binotto, E. (2006). Internet: Advantages and Disadvantages in Online Recruitment and Selection Processes. In M. K. Nakayama, B. S., Pilla, \& E. Binotto (Eds.), e-HR: Concepts and Practices of Electronic HR. Passo Fundo: Editora UPF.

Nielsen, J. (1994). Usability Inspection Methods. In Proceedings of the Conference Companion on Human Factors in Computing Systems (pp. 413-414). 
Nielsen, J. (2000). Designing Web Usability. New Riders.

Ostrofsky, M. (2013). Word of Mouse: 101 + Trends in How We Buy, Sell, Live, Learn, Work and Play. New York: Simon \& Schuster.

Palmer, J. W. (2002). Website Usability, Design, and Performance Metrics. Information Systems Research, 13, 151-167. https://doi.org/10.1287/isre.13.2.151.88

Phillips, J. M., \& Gully, S. M. (2015). Strategic Staffing (3rd ed.). London: Pearson.

Plessis, A. J., \& Frederick, H. (2012) Effectiveness of e-Recruiting: Empirical Evidence from the Rosebank Business Cluster in Auckland, New Zealand. Science Journal of Business Management, 2012, sjbm-126.

Rocha, T. V., Jansen, C. L. S., Lofti, E., \& Fraga, R. R. (2013). Exploratory Study on the Use of Social Networks in Building Customer Relationships. Revista Brasileira de Gestão de Negócios, 15, 262-282.

Rocha-de-Oliveira, S. (2009). Internships for University Students: Representations and Implications for the Professional Insertion of Brazilian and French Youth. Doctoral Dissertation, Universidade Federal do Rio Grande do Sul.

http://hdl.handle.net/10183/18329

Rocha-de-Oliveira, S., \& Piccinini, V. (2012). An Analysis of the Professional Insertion of Business Students in Brazil. Revista de Administração Mackenzie, 13, 44-75. https://doi.org/10.1590/S1678-69712012000200003

Rudich, J. (2000). Job Hunting on the Web. Link-Up, 17, 21-24.

Scalabrin, I. C., \& Molinari, A. M. C. (2013). The Importance of Supervised Internship Practice in Undergraduate Courses. Revista Unar, 7, 1-12.

Snell, S., Morris, S., \& Bohlander, G. W. (2016). Managing Human Resources (17th ed.). Boston, MA: Cengage Learning.

Stake, R. E. (2005). Qualitative Case Studies. In N. K. Denzin, \& Y. S. Lincoln (Eds.), The $S A G E$ Handbook of Qualitative Research (3rd ed.). Thousand Oaks, CA: SAGE Publishing.

Stoughton, J. W., Thompson, L. F., \& Meade, A. W. (2015). Examining Applicant Reactions to the Use of Social Networking Websites in Preemployment Screening. Journal of Business and Psychology, 30, 73-88. https://doi.org/10.1007/s10869-013-9333-6

Strauss, A., \& Corbin, J. (1998). Basics of Qualitative Research: Techniques and Procedures for Developing Grounded Theory (2nd ed.). Thousand Oaks, CA: SAGE Publishing.

Sullivan, J. (2003). A Dirty Little Secret: Nobody Is Reading Resumes (pp. 1-4). Electronic Recruiting Exchange.

Sullivan, J. (2011). Recruiting's Dirty Little Secrets: What You Don't Know Can Hurt You. Electronic Recruiting Exchange.

https://www.ere.net/recruitings-dirty-little-secrets-what-you-dont-know-can-hurt-you

Thomas, S. L., \& Ray, K. (2000). Recruitment and the Web: High-Tech Hiring. Business Horizons, 43, 43-52. https://doi.org/10.1016/S0007-6813(00)89200-9

Tose, M. G. L. S. (1997). The Evolution of Human Resource Management in Brazil. Master's Thesis, São Paulo: Pontifícia Universidade Católica de São Paulo.

Turban, D. B., Lau, C. M., Ngo, H. Y., Chow, I. H. S., \& Si, S. X. (2001). Organizational Attractiveness of Firms in the People's Republic of China: A Person-Organization Fit Perspective. Journal of Applied Psychology, 86, 194-206.

https://doi.org/10.1037/0021-9010.86.2.194

Yin, R. K. (2005). Case Studies: Plannning and Methods (3rd ed.). Thousand Oaks, CA: SAGE Publishing. 